\title{
Clara Cell Protein in Human Amniotic Fluid: A Potential Marker of Fetal Lung Growth
}

\author{
ALFRED BERNARD, NATHALIE THIELEMANS, ROBERT LAUWERYS, \\ JEAN-PAUL LANGHENDRIES, MICHEL VAN LIERDE, AND MARIA M. FREUND \\ Unit of Industrial Toxicology and Occupational Medicine [A.B., N.T., R.L.], Unit of Obstetrics \\ and Gynecology [M.V.L.], and Center of Medical Genetics [M.M.F.], Faculty of Medicine, \\ Catholic University of Louvain, B-1200 Brussels, Belgium, and Clinique St.-Vincent, B-4000 \\ Rocourt, Belgium [J.-P.L.]
}

\begin{abstract}
Clara cell protein $(\mathrm{CC} 16)$ is a $16-\mathrm{kD}$ protein secreted at the surface of respiratory airways by nonciliated bronchial and bronchiolar cells, including Clara cells. Using the same immunoassay as that recently developed for CC16 in lung lavage, we have measured CC16 in amniotic fluid samples from 100 normal fetuses and 51 fetuses with various pathologies. Ouchterlony immunodiffusion analysis showed a complete identity between $\mathrm{CC} 16$ in amniotic fluid and the protein in lung lavages of adults. CC16 was detectable in amniotic fluid from about the 15 th wk of pregnancy, then progressively increased until delivery, with a tendency to reach a plateau after the 30 th wk. Between the 15 th and the 39 th wk of pregnancy, the concentration of $\mathrm{CC} 16$ in amniotic fluid increased on average 25 times. The sex of the fetus did not influence the concentration of CC16 in amniotic fluid. Compared with expected values, levels of CC16 in amniotic fluid were on average not significantly altered in
\end{abstract}

\section{ABSTRACT}

cases of spina bifida $(n=9)$, anencephaly $(n=7)$, and trisomy $21(n=6)$. In contrast, CC16 was on average significantly decreased in cases of diaphragmatic hernia $(n$ $=6)$, trisomy $18(n=14)$, Turner syndrome $(n=4)$, and diabetic pregnancy $(n=5)$. In cases of diaphragmatic hernia, a relation emerged between the concentration of CC16 in amniotic fluid and both the weight of the lungs and the survivorship of the fetuses. The time course of CC16 in amniotic fluid during normal pregnancy and its reduction in pathologies associated with lung hypoplasia suggest that CC16 in amniotic fluid might serve as a marker of bronchial epithelium growth. (Pediatr Res 36: 771-775, 1994)
CC16, Clara cell protein
Abbreviations
RDS, respiratory distress syndrome

$\mathrm{CC} 16$ is a lung secretory protein that has been described in rodents and humans (1-5). Initially, CC16 was described as a specific product of the Clara cells, which are nonciliated cells predominantly localized in respiratory and terminal bronchioles (hence the name Clara cell protein). Recent evidence, however, indicates that the protein has a much wider distribution, being synthesized by nonciliated cells in large and small bronchi as well as in bronchioles (6). In addition, the protein is also secreted by the male urogenital tract from puberty on (7). It is identical to protein 1 , an $\alpha$-microprotein isolated from the urine of patients with tubular proteinuria (7), and presents a $61 \%$ sequence homology with rabbit uteroglobulin $(4,7,8)$. The $\mathrm{M}_{\mathrm{r}}$ of human CC16, determined by electro-

Received April 22, 1993; accepted June 23, 1994.

Correspondence and reprint requests: A. Bernard, Unit of Industrial Toxicology and Occupational Medicine, Catholic University of Louvain, Faculty of Medicine, 30.54 Clos Chapelle-aux-Champs, B-1200 Brussels, Belgium.

Supported by the Fonds de la Recherche Scıentifique Médicale (Belgium) and the Commission of the European Communities. A.M.B. is Research Director of the National Fund for Scientific Research, Belgium. spray ionization/mass spectrometry, is 15840 (9). The protein is composed of two identical subunits linked together by two disulfide bonds. Although the molecular size of CC16 may vary between animal species-it is $16908 \mathrm{D}$ in the rat (10) - the abbreviation CC16 will be used hereafter regardless of the species ${ }^{1}$.

The exact function of $\mathrm{CC} 16$ is yet to be determined. Evidence available to date suggests that it might be an immunosuppressive or antiinflammatory protein protecting the respiratory and urogenital tracts from exaggerated inflammatory reactions $(3,4,7,8)$. This evidence is based on the finding that $\mathrm{CC} 16$ inhibits phospholipase $\mathrm{A}_{2}$ and on the marked sequence similarity with rabbit uteroglobulin, which reportedly has immunosuppressive, antiinflammatory, antiproteinase, and antiphospholipase $A_{2}$ activity $(4,8)$.

\footnotetext{
${ }^{1}$ Because of anomalous migration properties, CC16 shows by SDS-PAGE an $\mathrm{M}_{\mathrm{r}}$ of 10000 . For this reason, $\mathrm{CC} 16$ has been misleadingly referred to in the literature as the $10-\mathrm{kD}$ Clara cell protein $(\mathrm{CC} 10)$.
} 
Using the same immunoassay as that recently applied to adult lung lavage (11), we have studied the time course of CC16 in human amniotic fluid during normal pregnancies and the influence of various fetal pathologies on the secretion of this lung protein in amniotic fluid.

\section{METHODS}

Amniotic fluids. The study was carried out on a total of 151 samples of amniotic fluid. With the exception of seven samples obtained at the time of delivery, all samples were collected by amniocentesis for prenatal diagnosis and were obtained from the same medical genetic center. One hundred samples were from pregnancies with a normal karyotype that resulted in the birth of normal healthy babies. They were collected for fetal karyotyping because of advanced maternal age or because of suspected pathology. Fifty-one samples were from abnormal pregnancies including nine cases of spina bifida (mean gestational age, range: $24 \mathrm{wk}, 16-37 \mathrm{wk}$ ), six cases of diaphragmatic hernia ( $33 \mathrm{wk}, 16-38 \mathrm{wk}$ ), 14 cases of trisomy 18 (21.6 wk, 15-36 wk), six cases of trisomy 21 (21.8 wk, 16-32 wk), four cases of Turner syndrome $(45, \mathrm{X} 0)(20 \mathrm{wk}, 16-24 \mathrm{wk})$, seven cases of anencephaly (19.6 wk, 14-22 wk), and five cases from insulindependent diabetic women (18.4 wk, 16-25 wk). Gestational age was determined from the first day of the last menstrual cycle and confirmed by ultrasonography. The samples were stored at $-20^{\circ} \mathrm{C}$ for variable periods of time. As shown previously (12), CC16 is stable under these conditions.

Assay of CC16. The concentration of CC16 in amniotic fluid was determined by the same immunoassay as that recently used for the analysis of the protein in bronchoalveolar lavages (11). A detailed description of this immunoassay, which relies on the agglutination of latex particles, in regard to its application to the determination of CC16 (or protein 1) in urine has been published (12). The assay uses the anti-protein 1 antibody from Dakopatts (Glostrup, Denmark) and, as standard, the protein purified in our laboratory (7). CC16 was determined on the supernatant obtained by centrifuging the amniotic fluids at $85-90 \times g$ for $10 \mathrm{~min}$. The limit of detection of the assay, defined as the protein concentration agglutinating $10 \%$ of the particles, lies around $0.3-0.4 \mu \mathrm{g} / \mathrm{L}$. However, because amniotic fluids must be diluted at least 40 times to get a linear response, the lowest concentration measurable with precision was $15 \mu \mathrm{g} / \mathrm{L}$. (This value was adopted for the graphic representation of samples with undetectable CC16.)

Statistical analysis. All statistical tests were done with Statview SE software (13). The effects of gestational age and sex on the concentrations of CC16 (log transformed) were examined by stepwise regression analysis. Expected values were calculated by a polynomial regression. Differences between values during normal pregnancy and those in pathologic pregnancies (expressed as a percentage of expected values and then log trans- formed) were assessed by an analysis of variance followed by Dunett's multiple comparison test. Results are reported as statistically significant at $p<0.05$.

\section{RESULTS}

Accuracy and specificity of the assay. The accuracy of the assay was tested by adding purified CC16 (7) to six amniotic fluid samples to increase their concentration by $200 \mu \mathrm{g} / \mathrm{L}$. The analytical recovery (measured within $48 \mathrm{~h}$ ) averaged 104\% (SD, 8\%). In Ouchterlony immunodiffusion analysis, CC16 from amniotic fluid showed a complete identity with the protein present in bronchoalveolar lavage of adults or that purified from tubular proteinuria (Fig. 1). Pooled amniotic fluids from five normal fetuses were fractionated by fast protein liquid chromatography on Sephacryl S-200 (Pharmacia-LKB Biotechnology, Uppsala, Sweden), and CC16 was assayed in the eluted fractions by latex immunoassay (12). CC16 eluted as a single component with an apparent size of approximately $16 \mathrm{kD}$, which was indistinguishable from that of the native protein or the protein present in lung lavage of adults (results not shown).

CC16 in amniotic fluid from normal pregnancies. In stepwise regression analysis, CC16 levels in normal amniotic

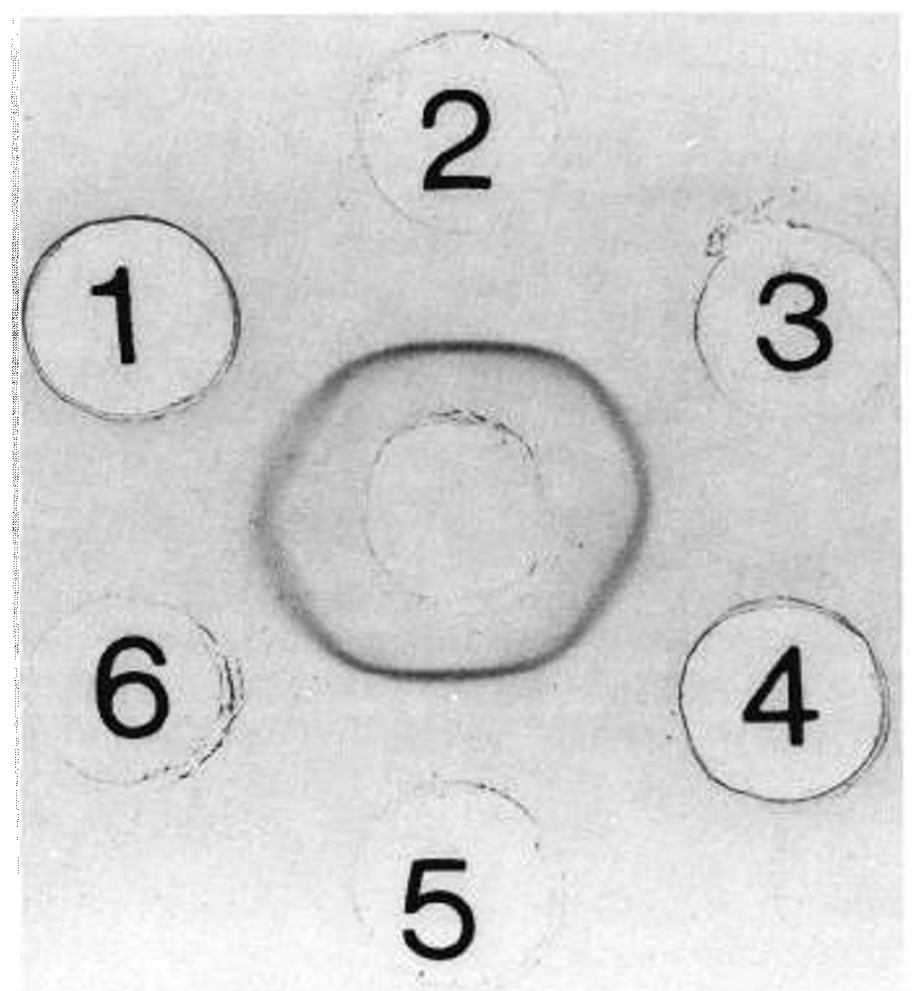

Figure 1. Ouchterlony immunodiffusion analysis of amniotic fluid from two pregnant women (wells 1 and 4), purified CC16 (wells 2 and 5), and bronchoalveolar lavage fluid from two healthy nonsmokers (wells 3 and 6). The central well contained $20 \mu \mathbf{L}$ of anti-CC16 antibody (antiprotein 1 antibody from Dakopatts), and other wells contained 20 (wells 2 and 5) or $40 \mu \mathrm{L}$ (wells 3, 4, and 6) of solutions with CC16 concentrations between 10 and $50 \mathrm{mg} / \mathrm{L}$. After $24 \mathrm{~h}$ of diffusion, the plate was washed, dried, and stained with Coomassie brilliant blue. 
fluid were independent of the sex of the fetus (partial $r^{2}=$ $0.015, p=0.08$ ) but highly correlated with the gestational age (partial $r^{2}=0.67, p=0.0001$ ). The time course of $\mathrm{CC} 16$ in amniotic fluid during normal pregnancy is depicted in Figure 2. The protein was detectable on average from the 15th wk of pregnancy, then progressively increased until the delivery, with a tendency to reach a plateau after wk 30 . Between the 15th wk and the end of pregnancy, the concentration of $\mathrm{CC} 16$ in amniotic fluid was multiplied on average by a factor of 25 .

CC16 in amniotic fluid from pathologic pregnancies. Values of CC16 in amniotic fluid from various abnormal pregancies are shown in Figure 3. For the statistical evaluation of these data, we expressed all the results as percentages of the expected values, the latter being derived from the second-degree polynomial of Figure 2. The levels of CC16 in amniotic fluid in cases of spina bifida (geometric mean, $141 \%$ ), anencephaly $(72.4 \%$ ), and trisomy $21(111 \%)$ were not significantly different from that calculated in controls $(108 \%)$. In contrast, mean values observed in fetuses with diaphragmatic hernia $(26.9 \%)$, Turner syndrome (19.7\%), or trisomy $18(50 \%)$ or from diabetic mothers $(52.4 \%)$ were significantly lower than expected whether the comparison was made with normal fetuses or with other abnormal fetuses $(101 \%, n=22)$. In view of the variable onset of CC16 in normal amniotic fluid during pregnancy (Fig. 2), CC16 is likely to be a reliable index of fetal lung growth only in samples collected after the 20th wk of pregnancy. To further assess the potential of CC16 to detect abnormal growth, we calculated the lowest $95 \%$ probability limit of the expected $\mathrm{CC} 16$ values in amniotic fluid of normal fetuses with a gestational age greater than $20 \mathrm{wk}(n=30)$. The $\mathrm{CC} 16$ value was below this threshold $(40 \%)$ in the three fetuses with Turner syndrome and in four of the five fetuses with diaphragmatic hernia aged greater than 20 wk. CC16 in amniotic fluid was also below this threshold in two of the eight fetuses with trisomy 18 . In contrast, no value of $\mathrm{CC} 16$ laid below the $95 \%$ limit in the 12 other

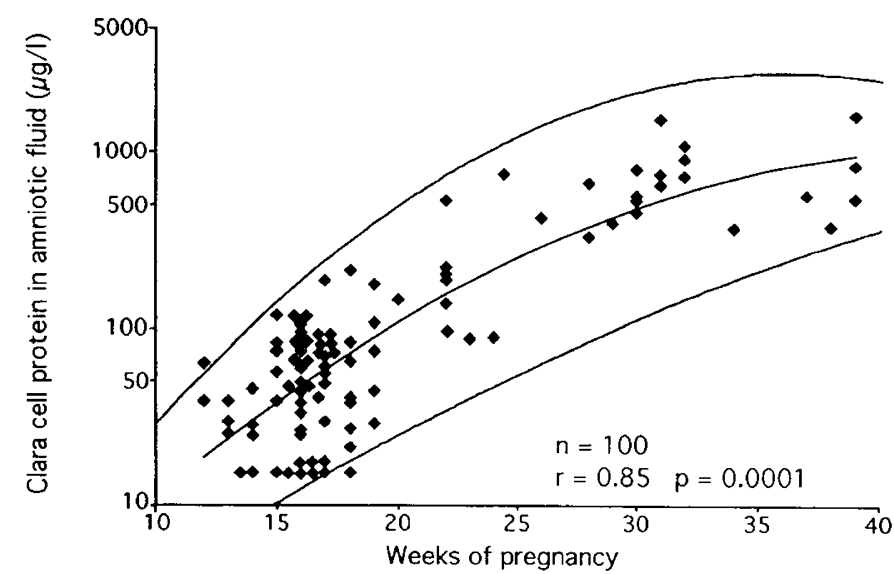

Figure 2. Time course of $\mathrm{CC} 16$ in amniotic fluid during normal pregnancy. The equation of the regression line is: $\log y=-0.31+0.15 x-$ $1.710^{-3} \mathrm{x}^{2}$. The area between the upper and lower lines represents the $90 \%$ confidence interval.

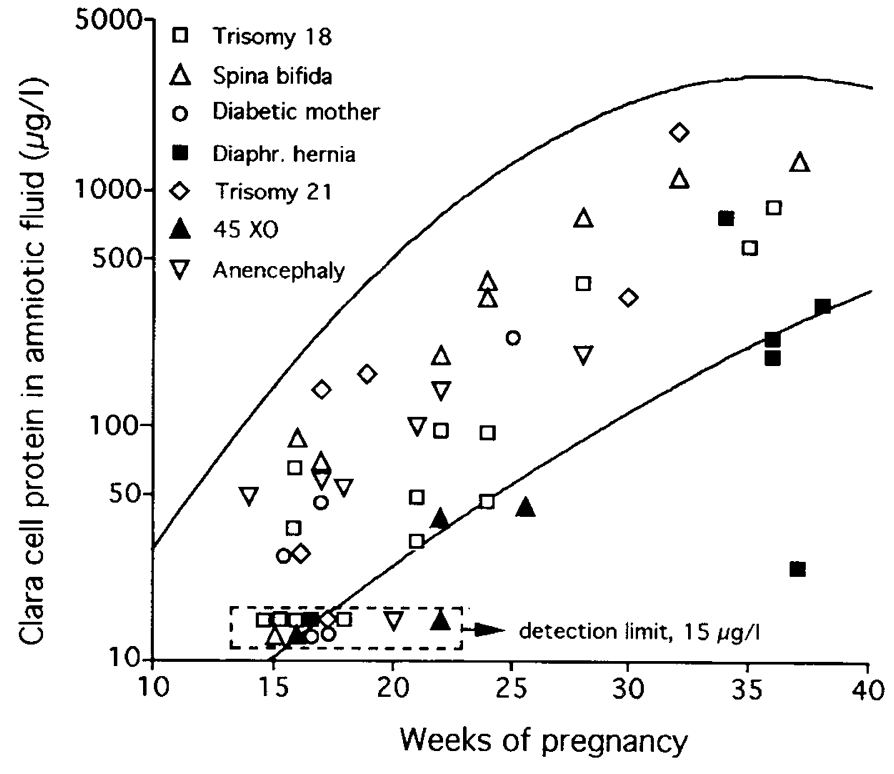

Figure 3. $\mathrm{CC} 16$ in amniotic fluid in different types of pathologic pregnancies. The two lines represent the $90 \%$ confidence interval of the regression line of Figure 2. Diaphr., diaphragmatic.

fetuses of abnormal pregnancies with a gestational age greater than $20 \mathrm{wk}$ (i.e. six with spina bifida, two with trisomy 21 , three with anencephaly, and one fetus from a diabetic mother).

Table 1 compares the values of $\mathrm{CC} 16$ in amniotic fluid with the total lung weight and the survivorship of fetuses with diaphragmatic hernia and of three other abnormal fetuses for which information on lung weight and survivorship was available. Of the six fetuses with diaphragmatic hernia, five died between 1 and $34 \mathrm{~h}$ after delivery despite appropriate medical assistance and one survived. It is interesting to note that the concentration of $\mathrm{CC} 16$ in amniotic fluid was normal (109\% of the expected value) in the latter case and much lower in other cases, the lowest value $(2.5 \%$ of the expected value) being observed with the baby who survived only $1 \mathrm{~h}$. All fetuses who died and were autopsied had hypoplastic lungs (total lung weight, 4.1 to $17.2 \mathrm{~g} ; 8.4$ to $35 \%$ of the expected value). Table 1 also reports values from three other abnormal fetuses, two anencephalic and one with Turner syndrome. The latter subject was of interest because he had a pronounced lung hypoplasia that was mirrored in the level of CC16 in amniotic fluid (16 and 15\% of the expected values, respectively). When all cases are combined, a highly significant correlation emerges between $\mathrm{CC} 16$ in amniotic fluid and the total lung weight (both expressed as a percentage of the expected value, $r=0.94, p=$ $0.002, n=7)$.

\section{DISCUSSION}

CC16 was measured in amniotic fluid with an immunoassay initially developed for a urinary microprotein called protein 1 identical with $\mathrm{CC} 16(12)$ and recently applied to the analysis of CC16 in bronchoalveolar lavage (11). A reaction of complete identity was demonstrated 
Table 1. Outcome, lung weight, and CC16 in amniotic fluid in several cases of abnormal pregnancy*

\begin{tabular}{|c|c|c|c|c|c|c|c|c|c|}
\hline \multirow{2}{*}{$\begin{array}{l}\text { Type of } \\
\text { pathology }\end{array}$} & \multirow{2}{*}{$\begin{array}{l}\text { Birth } \\
\text { (wk) }\end{array}$} & \multirow{2}{*}{$\begin{array}{l}\text { Survival } \\
\text { time }(\mathrm{h})\end{array}$} & \multicolumn{4}{|c|}{ Lung weight (g) } & \multicolumn{3}{|c|}{ CC16 in amniotic fluid } \\
\hline & & & Left & Right & Total & $\%$ expected & Time (wk) & $\mu \mathrm{g} / \mathrm{L}$ & $\%$ expected \\
\hline Diaphr & 37 & 1 & 2.1 & 2 & 4.1 & 8.4 & 36 & 25 & 2.5 \\
\hline Diaphr & 41 & 2 & 1.5 & 6.8 & 8.3 & 17 & 36 & 235 & 29 \\
\hline Diaphr & 36 & 24 & 3 & 11 & 14 & 31.8 & 16 & 15.5 & 32 \\
\hline Diaphr & 38 & 24 & & & & & 36 & 214 & 26 \\
\hline Diaphr & 39 & 34 & 4.7 & 12.5 & 17.2 & 35 & 38 & 327 & 36 \\
\hline Diaphr & 38 & Survived & & & & & 34 & 767 & 109 \\
\hline Anenceph & 29 & Abortion & 2.5 & 2.5 & 5 & 28 & 28 & 198 & 53 \\
\hline Anenceph & 23 & Abortion & 4.5 & 5 & 9.5 & 86 & 22 & 141 & 93 \\
\hline $45, \mathrm{XO}$ & 26 & Abortion & 2.1 & 2.3 & 4.4 & 16 & 24 & 45 & 15 \\
\hline
\end{tabular}

* Diaphr, diaphragmatic hernia; anencephal, anencephaly; 45,XO, Turner syndrome.

by Ouchterlony immunodiffusion analysis between $\mathrm{CC} 16$ in amniotic fluid and the protein in lung lavages of adults or that purified from pathologic urine. The protein occurring in these three fluids also showed by gel filtration an identical $\mathrm{M}_{\mathrm{r}}$ around 16000 .

At the present time, two sources of $\mathrm{CC} 16$ have been identified: nonciliated columnar cells of the bronchial and bronchiolar epithelium, in particular Clara cells (6), and, from puberty on, the male urogenital tract (7). The absence of a sex effect on CC16 in amniotic fluid allows us to rule out the latter source and to conclude that most CC16 in amniotic fluid probably originates from the fetal lung. This interpretation is supported by the fact that the time course of $\mathrm{CC} 16$ in normal amniotic fluid is consistent with what is known about the development of Clara cells (14). These cells are thought to develop during the second half of gestation from primitive nonciliated cells of the terminal airways. By 18-19 wk of gestation, the domelike apical protrusion characteristic of mature cells has formed. Maturation involves a gradual loss of cytoplasmic glycogen and the appearance of electron-dense granules that probably contain CC16. On the other hand, it is well established that by $15-16 \mathrm{wk}$, the fetus has sufficient breathing activity to move small amounts of amniotic fluid in and out of the respiratory tract, which can explain the release of $\mathrm{CC} 16$ into amniotic fluid. The timing of CC16 in human amniotic fluid resembles also that of CC16 in the amniotic fluid and the developing lung of rat. Singh et al. (15) have noted in rat a progressive increase of $\mathrm{CC} 16$ in both lung and amniotic fluid between $\mathrm{d} 18$ and 21 of gestation. The average increase was only 3.8 -fold in amniotic fluid but reached 30 -fold in the lung, which is comparable to the factor of 25 observed in the present study for amniotic fluid. In hamsters, too, CC16 was immunolocalized by electron and light microscopy in the fetal lung from d 15 of gestation, and an increasing amount of labeling was noted until birth and during the first few weeks after birth (16).

Results obtained in pathologic pregnancies are also consistent with an exclusively pulmonary origin of $\mathrm{CC} 16$ in amniotic fluid. The concentrations of $\mathrm{CC} 16$ in amniotic fluid were markedly decreased in fetuses with diaphragmatic hernia, which is a well-known cause of lung hypoplasia (14). The concentration of CC16 in amniotic fluid correlated with both the weight of the lungs and the survivorship of the fetuses with diaphragmatic hernia (Table 1). A pronounced decrease of CC16 was also found in fetuses with Turner syndrome, resulting most likely from lung hypoplasia, inasmuch as the three cases we have examined showed by echography signs of hygroma and lymphedema hindering the development of lungs. In one case, this was confirmed by the anatomopathologic examination (Table 1). It is interesting to note that when one considers only fetuses with a gestational age of more than $20 \mathrm{wk}$ (i.e. for whom $\mathrm{CC} 16 \mathrm{can}$ be detected in amniotic fluid) all fetuses with Turner syndrome or a diaphragmatic hernia (with the exception of the subject who survived) had values of CC16 in amniotic fluid below the lowest $95 \%$ probability limit, whereas the values for all other abnormal fetuses except two with trisomy 18 fell inside these limits. The mean concentrations of CC16 in amniotic fluid were also slightly lower in the case of trisomy 18 and in diabetic pregnancy, two situations that may be associated with lung hypoplasia or immaturity $(14,17)$.

Tests of fetal lung maturity presently available measure phospholipids of the pulmonary surfactant in amniotic fluid and aim to assess the risk of the neonatal RDS. The most commonly used test involves the lecithin/ sphingomyelin ratio, but other markers are also available such as the concentration of lecithin or phosphatidylglycerol, the foam stability index, or the surfactant apoproteins, which appear to have a better predictability in diabetic pregnancy, a situation associated with a particularly elevated risk of neonatal RDS (18-21). All these tests are based on surfactant constituents-which are deficient in neonatal RDS-and thus reflect the maturation of lung alveoli. Little attention has been paid so far to potential markers of the development of airway cells. The low- $\mathrm{M}_{\mathrm{r}}$ antileukoprotease (a protein secreted by both Clara cells and goblet cells) has been shown to be present in bronchiolar epithelium by the 38th wk of gestation, but to our knowledge this protein has not yet been investigated in amniotic fluid (22). CC16 thus seems to be the first potential marker of bronchial epithelium development to have been monitored in human amniotic fluid. The time course of $\mathrm{CC} 16$ during normal pregnancy and its reduction in abnormal pregnancies associated with lung 
hypoplasia suggest that $\mathrm{CC} 16$ in amniotic fluid might be a useful gestational age-dependent marker of lung growth. A practical advantage of CC16 over other lung development markers is its insensitivity to unintentional contamination of the amniotic sample by blood, because CC16 occurs in serum only in trace amounts (9).

Acknowledgments. The authors thank X. Dumont for his expert technical assistance. Dr. J. C. Daniel from RhônePoulenc Industrie, France, is gratefully acknowledged for providing us with batches of polystyrene latex particles (ESTAPOR K109).

\section{REFERENCES}

1. Singh G, Katyal SL 1984 An immunologic study of the secretory products of rat Clara cell. J Histochem Cytochem 32:49-54

2. Singh G, Katyal SL, Ward JM, Gottoron SA, Wong-Chong ML, Riley EY 1985 Secretory proteins of the lung in rodents: immunocytochemistry. J Histochem Cytochem 33:564-570

3. Singh G, Katyal SL, Ward JM, Brown JM, Philips S, Kennedy AL, Anthony J, Squeglia NVA 1988 Amino-acid and cDNA nucleotide sequences of human Clara cell $10 \mathrm{kDa}$ protein. Biochim Biophys Acta 950:329-337

4. Singh G, Katyal SL, Brown WE, Kennedy AL, Singh U, Wong-Chong ML 1990 Clara cell $10 \mathrm{kDa}$ protein (CC10): comparison of structure and function to uteroglobulin. Biochim Biophys Acta 1039:348-355

5. Singh G, Singh J, Katyal SL, Brown WE, Kramps JA, Paradis IL, Dauber JH, Macpherson TA, Squeglia N 1988 Identification, cellular localization, isolation and characterization of human Clara cell specific $10 \mathrm{kD}$ protein. $\mathbf{J}$ Histochem Cytochem 1:73-80

6. Broers JLV, Jensen SM, Travis WD, Pass H, Whitsett JA, Singh G, Katyal SL, Gazdar AF, Minna JD, Linnoila RI 1992 Expression of surfactant associated protein-A and Clara cell 10 kilodalton mRNA in neoplastic and nonneoplastic human lung tissue as detected by in situ hybridization. Lab Invest 66:337-345

7. Bernard A, Roels H, Lauwerys R, Witers R, Gielens C, Soumillion A, Van Damme J, De Ley M 1992 Human urinary protein 1: evidence for identity with the Clara cell protein and occurrence in respiratory tract and urogenital tract secretions. Clin Chim Acta 207:239-249
8. Jackson PJ, Turner R, Keen JN, Booksbank RA, Cooper EH 1988 Purification and partial amino acid sequence of human urine protein 1. J Chromatogr 452:359-367

9. Bernard AM, Dumont X, Roels H, Lauwerys R, Dierynck I, De Ley M, Stoobant V, de Hoffman E 1993 The molecular mass and concentrations of protein 1 or Clara cell protein in biological fluids: a reappraisal. Clin Chim Acta 223:189-191

10. Umland TC, Swaminathan S, Furey W, Singh G, Pletcher J, Sax M 1992 Refined structure of rat Clara cell $17 \mathrm{kDa}$ protein at $3.0 \mathrm{~A}$ resolution. $\mathrm{J} \mathrm{Mol}$ Biol 224:441-448

11. Bernard A, Marchandise FX, Depelchin S, Lauwerys R, Sibille Y 1992 Clara cell protein in serum and bronchoalveolar lavage. Eur Respir J 5:1231-1238

12. Bernard A, Lauwerys R, Noel A, Vandeleene B, Lambert A 1991 Determination by latex immunoassay of protein 1 in normal and pathological urine. Clin Chim Acta 201:231-246

13. Fedman D, Gagnon J, Hofmann R, Simpson J 1988 Statview SE+ Graphics. Abacus Concepts, Inc, Berkeley, CA

14. Jeffery PK, Gaillard D, Moret S 1992 Human airways secretory cells during development and in mature airway epithelium. Eur Respir J 5:93-104

15. Singh G, Katyal SL, Wong-Chong ML 1986 A quantitative assay for a Clara cell-specific protein and its application in the study of development of pulmonary airways in the rat. Pediatr Res 20:802-805

16. Strum JM, Singh G, Katyal SL, McDowell EM 1990 Immunochemical localization of Clara cell protein by light and electron microscopy in conducting airways of fetal and neonatal hamster lung. Anat Rec 227:77-86

17. Jones KL 1988 Smith's Recognizable Patterns of Human Malformations, 4th Ed. WB Saunders, Philadelphia

18. Gluck L, Kulovich MV, Borer RC, Bremer PH, Andersen GG, Spellacy WN 1971 Diagnosis of the respiratory distress syndrome by amniocentesis. Am J Obstet Gynecol 115:440-445

19. Gluck L, Kulovich MV 1973 Lecithin-sphingomyelin ratios in amniotic fluid in normal and abnormal pregnancy. Am J Obstet Gynecol 115:539-546

20. Mueller-Heubach E, Caritis SN, Edelstone DI, Turner JH 1978 Lecithin/ sphingomyelin ratio in amniotic fluid and its value for the prediction of neonatal respiratory distress syndrome in pregnant diabetic women. Am J Obstet Gynecol 130:28-34

21. Katyal SL, Amenta JS, Singh G, Silverman JA 1984 Deficient lung surfactant apoproteins in amniotic fluid with mature phospholipid profile from diabetic pregnancies. Am J Obstet Gynecol 148:48-53

22. De Water R, Willems LNA, Van Muijen GNP, Franken C, Fransen JAM, Dijkman JH, Kramps JA 1986 Ultrastructural localization of bronchial antileukoprotease in central and peripheral human airways by a gold-labeling technique using monoclonal antibodies. Am Rev Respir Dis 133:882-890 